\title{
Life cycle assessment in housing projects: an applied study for the context of Northeast Brazil
}

\author{
R. M. R. Tabosa \& G. J. A. Silva \\ Department of Architecture and Urbanism, \\ Federal University of Paraiba, Brazil
}

\begin{abstract}
Today, sustainability is an important and crucial issue regarding several activities performed by man. The professionals in the field of architecture and urbanism are increasingly being spurred to minimize environmental impacts and building costs. In developing cities, such as those from Northeast Brazil, the environment impact tends to be larger; therefore, the use of sustainable architecture becomes much more relevant. In this scenario, numerous sustainability practices are researched and developed to be applied to architectural projects, such as the Life Cycle Assessment (LCA) technique, which might be used into architecture housing projects. Therefore, this research aims at establishing guidelines for sustainable building practices and low technology architecture in Northeast Brazil, mainly focusing on the state of Paraíba, based on parameters such as materials; energy, waste and environmental comfort. Because of this, four examples of internationally environmentally certified multi-family dwellings which carry LCA process in their construction have been chosen to be a case study, to associate them with the local reality outlined in problems of possible forms of implementation of feasible alternatives of sustainability in construction. It was found that there are viable practices for sustainable architecture in accordance with the local reality of the life cycle assessment process amongst the previously established parameters. The results provide evidence that it is achievable to apply the concepts of sustainability and efficiency in local architecture without using big technology, construction techniques or high costs.
\end{abstract}

Keywords: Life Cycle Assessment, sustainable architecture, Northeast Brazil. 


\section{Introduction}

Today, sustainability is an imperative and conclusive issue into several activities performed by man. The construction industry is one of prime responsible for an important share of the Gross Domestic Product (GDP), as well as one the greatest villains regarding the environmental issue. Therefore, professionals must reduce environmental impacts and cost of building.

In northeast Brazil, as well as the rest of the country, the impact on the environment tends to be higher in developing cities. Among these cities, we must highlight the ones sited in the state of Paraíba, which is known as one of the least developed states of the country. All this makes the implementation of sustainable architecture more and more important, especially in a moment where Brazil faces national crisis.

In this scenario, several sustainable practices are sought for and developed to be applied in architectural projects, such as the technique of life cycle assessment (LCA), this is an environmental performance assessment tool, which takes the entire cycle of existence into account and has increasingly been used in construction. The LCA allows investigation of opportunities for improvement in construction, offering, in particular information on the environment impacts [1]. Through this, it is possible to identify and quantify aspects such as material flow, energy supply, water use and waste generated by the building through its cycle, covering the material extraction and use, reuse, recycling or disposal as part of the flows analyzed.

According to Edwards [2] it is necessary to adopt the mindset of the four "Rs", which are, reduce, reuse, recycle and rehabilitate in the act of designing, in order to contemplate the whole concept of Life Cycle Analysis and therefore achieve a better quality of life, without causing a global disaster.

A building must always aim for energy efficiency, as well as a connection with the "human health", which means, it must target issues such as environmental comfort, elimination of pollution and search for stimulating and welcoming environments [2].

In general, we can affirm that the LCA in the field of architecture and construction takes into consideration several analyzing factors, including study parameters such as materials, energy, water, environmental comfort and waste.

Currently, there are many famous architectural designs that take into consideration the process of LCA in its execution, an example of this is Bedzed, a mixed-use development located in south London, designed by Bill Dunster Architects. The project is a sustainable architecture experiment famous for intending to reduce carbon emissions during construction, maintenance and use of the building, and shows that it can be repeated everywhere.

Other examples are also found in Sweden, which has as one of its priorities the growth of sustainable development, emerging the idea of building the Hammarby district in the city of Stockholm in order to reduce energy consumption, water reuse and waste management.

The first Passive House, located in Darmstdat and idealized by professors Adamson and Feist, was built aiming to show that a building may have an internal 
thermal comfort without artificial sources of heating and cooling during the seasons, being also an example which replication is possible. Furthermore, the Linked Hybrid, a residential complex located in Beijing, designed by architect Steven Holl which aimed sustainable development and self-sufficiency.

From this perspective, a theoretical review and case studies were carried out in order to establish guidelines for sustainable construction practices and "low tech" architecture in Northeast Brazil, focusing mainly in the state of Paraíba, based on study parameters such as materials, energy, water, environmental comfort and waste.

\section{Methodological procedures}

\subsection{Study area}

The Northeast region is one of the five regions of Brazil and consists of nine states, including the state of Paraíba (figure 1). It is a region with vast territorial extension, composed of four different types of climates: semiarid, tropical, equatorial and coastal.

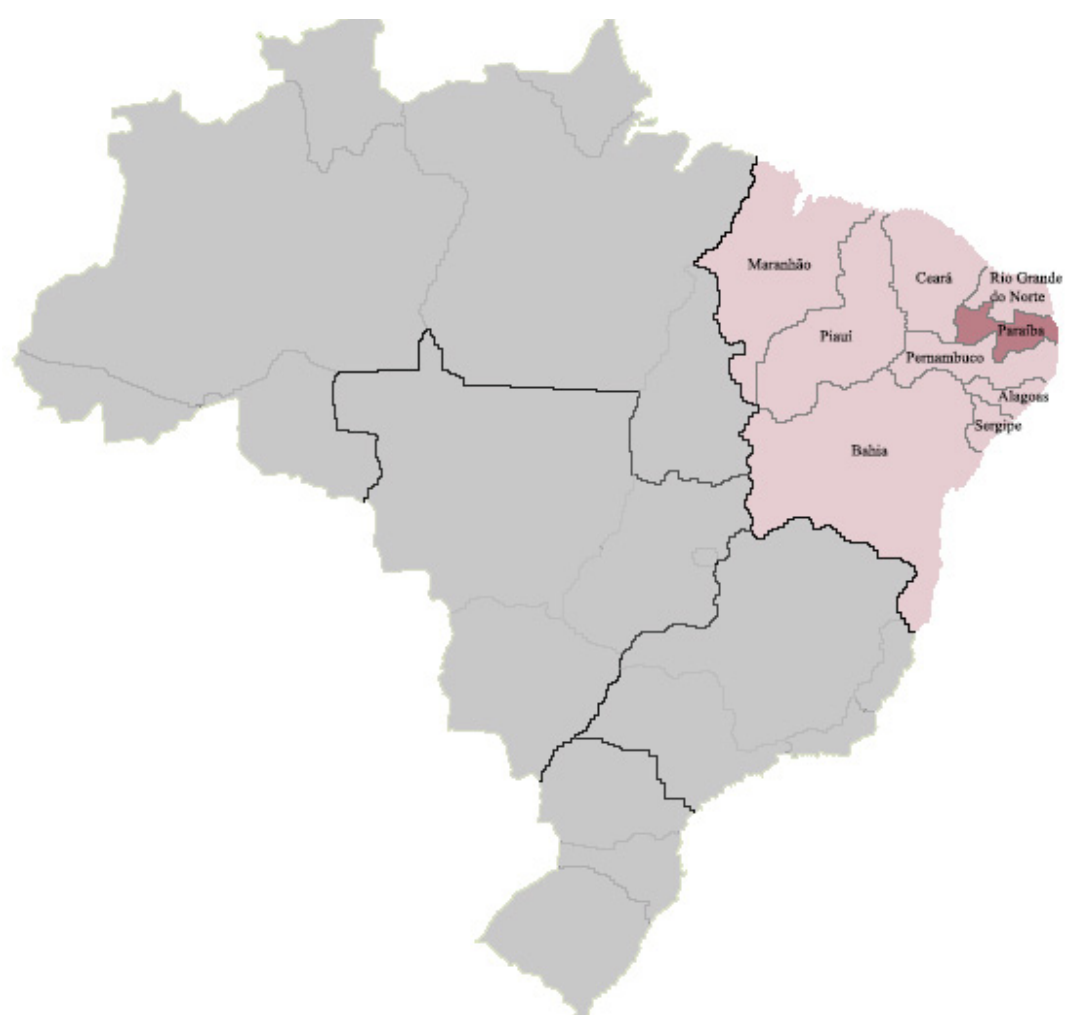

Figure 1: Map of Brazil highlighting the Northeast region with a focus on Paraíba state. (Source: Google edited by the authors.) 
The state of Paraíba is located in the east of the Northeast region, and is bordered by the states of Rio Grande do Norte to the north, Pernambuco to the South, Ceará to the West and Atlantic Ocean to the east. It is the fourteenth most populous state in Brazil (IBGE 2015), and João Pessoa is its capital city.

Located near Equator, Paraíba has warm climate and high temperatures throughout the year. In the coastal region, the climate is classified as coastal, with average temperatures around $24^{\circ} \mathrm{C}$, with regular rains and relatively high rainfall. In most of the countryside, the climate is semiarid, with average temperatures around $26^{\circ} \mathrm{C}$ and low rainfall [3].

\subsection{Parameters for LCA}

In order to establish guidelines for sustainable construction practices and "low tech" architecture, four cases of environmentally certified international multifamily housing in accordance with the principles of LCA were studied, aiming to obtain sustainable principles that can be used in the reality of Paraíba. The four selected housing projects were the BedZed in England; Hammarby Sjostad in Sweden; Linked Hybrid in China and the Passive House in Germany. The buildings were selected based on the parameters established previously: material, energy, water, environmental comfort and waste.

\subsubsection{Material}

The environmental evaluation of materials takes into consideration factors such as the extraction phase, transport, use, maintenance and disposal, aiming reduction on the environmental impact, energy and transportation costs [2].

Table 1: Guidelines adopted regarding materials in the case studies.

\begin{tabular}{|c|c|c|}
\hline Buildings & Bedzed & Hammarby Sjostad \\
\hline \multirow{3}{*}{ Guidelines used } & $\begin{array}{c}\text { Use of low } \\
\text { environmental impact } \\
\text { materials in its } \\
\text { construction, used in } \\
\text { their natural form and } \\
\text { reused or recycled } \\
\text { whenever possible, and } \\
\text { obtained near the } \\
\text { construction site [4]. }\end{array}$ & $\begin{array}{c}\text { Use of environmentally } \\
\text { friendly materials that } \\
\text { cause the minimum } \\
\text { impact on the } \\
\text { environment, certified } \\
\text { by the Swedish } \\
\text { government, and } \\
\text { recyclable when } \\
\text { technically and } \\
\text { economically feasible } \\
\end{array}$ \\
& & [5]. \\
\hline
\end{tabular}

\subsubsection{Energy}

The housing projects show that the main goal in this subject matter is to have most of the energy consumed generated locally or using renewable energy sources. 
Table 2: Guidelines adopted regarding energy in the case studies.

\begin{tabular}{|c|c|c|c|}
\hline Buildings & Bedzed & Hammarby Sjostad & Linked hybrid \\
\hline \multirow{4}{*}{$\begin{array}{c}\text { Guidelines } \\
\text { used }\end{array}$} & $\begin{array}{c}\text { Use of solar } \\
\text { energy through } \\
\text { photovoltaic cells } \\
\text { and use of the } \\
\text { cogeneration } \\
\text { system Combined } \\
\text { Heat and Power } \\
\text { (CHP) [4]. }\end{array}$ & $\begin{array}{c}\text { Use of renewable } \\
\text { energy sources: } \\
\text { wind, biogas and } \\
\text { solar and use of the } \\
\text { cogeneration } \\
\text { system Combined } \\
\text { Heat and Power } \\
\text { (CHP) [5]. }\end{array}$ & $\begin{array}{c}\text { Geothermal } \\
\text { heating system. }\end{array}$ \\
& \multicolumn{2}{|c}{} & \\
\hline
\end{tabular}

\subsubsection{Water}

All examples, BedZed; Hammarby Sjosted; Linked Hybrid and Passive House present systems for reuse of rainwater and sewage, which is a key point to this issue and very important for the environmental evaluation of a building.

All buildings use green roofs to assist the collection and storage of water, which after treatment will feed toilet flushes and will be used to water gardens. Other solutions such as the use of household appliances (washing machine, taps, showers...) which consume less energy and water were also taken.

\subsubsection{Environmental comfort}

The guidelines adopted regarding environmental comfort in the case studies are shown in Table 3.

Table 3: Guidelines adopted regarding environmental comfort in the case studies.

\begin{tabular}{|c|c|c|c|}
\hline Buildings & Bedzed & Linked hybrid & Passive House \\
\hline $\begin{array}{l}\text { Guidelines } \\
\text { used }\end{array}$ & $\begin{array}{l}\text { Passive heating, } \\
\text { cooling, lighting } \\
\text { and ventilation } \\
\text { systems. Use of } \\
\text { "Cowls" for } \\
\text { passive } \\
\text { ventilation. Use } \\
\text { of crossed } \\
\text { ventilation [4]. }\end{array}$ & $\begin{array}{l}\text { Recessed } \\
\text { openings in the } \\
\text { façade. } \\
\text { Ventilation by } \\
\text { displacement. } \\
\text { Capture of } \\
\text { natural light (all } \\
\text { apartments } \\
\text { receive light in at } \\
\text { least one of the } \\
\text { façades) [6]. }\end{array}$ & $\begin{array}{c}\text { Passive heating, } \\
\text { cooling, lighting } \\
\text { and ventilation } \\
\text { systems. } \\
\text { Mechanical } \\
\text { ventilation with } \\
\text { heat recovery. } \\
\text { Minimal thermal } \\
\text { bridges. High } \\
\text { isolation levels. } \\
\text { Guidance turned } \\
\text { south to capture } \\
\text { heat. Air } \\
\text { permeability [7]. }\end{array}$ \\
\hline
\end{tabular}




\subsubsection{Waste}

Life Cycle Assessment shows that construction waste should be reduced, reused or recycled whenever possible.

In Hammarby, waste can be used in two different ways, one way is power generation system and the other is recycling into agricultural fertilizer. There is great incentive for recycling, and the garbage collection system facilitates this process, as it is underground and pneumatic. Collector's dump accumulates garbage inside the tubes, where it is transferred in the vacuum to the collecting centers, separated by containers [5].

\section{LCA: an applied study to the Northeast context (Paraíba)}

\subsection{Sustainable guidelines}

Based on the study and research of the four architectural projects presented, it was possible to develop guidelines regarding sustainable architecture according to the Life Cycle Analysis for the Northeast region, focusing on the state of Paraíba, following the parameters established in the study of the buildings.

The Life Cycle Analysis shows that the materials must be environmentally certified; local; of low energy in its manufacturing process; of easiness for recycling/reusing; and which generates less waste and pollution to the environment. Some materials, in the context studied, which are in these requirements, are bamboo, gypsum and construction with earth. The construction waste is also in this context, with a possibility of being used as aggregate to make other building materials.

Bamboo is a material which has a wide use in the field of architecture and engineering. In addition to the aesthetic appeal in architectural projects, bamboo has many other advantages such as: light weight, easy transportation and storage; absorption of $\mathrm{CO}_{2}$ instead of emission; availability in the market. Besides this it doesn't require the use of major technologies to be used; the plantation speed is fast; it uses solar energy in the manufacturing process; it is a material that generates little waste in construction; as it is biodegradable, its debris do not cause major impacts to the environment [8]. Obviously, bamboo has some disadvantages, such as decay with moisture variation and need for treatment to become a durable material among others, but these drawbacks can be overcome and are minimized when compared to the listed advantages.

The main production of gypsum deposits is in northeast Brazil, in the state of Pernambuco, located a few hours from Paraíba [9]. This gypsum deposits supplies $90 \%$ of the domestic market [9] and therefore it is a local material. In addition, gypsum is an inexpensive material that promotes the reduction of waste in the construction, it is easy to use and has fast construction, it has an adequate resistance to construction and is resistant to fire.

Earth is a material which contributes to sustainable construction, the use of raw blocks of land contributes to reduce the serious problem of desertification, which is found in Northeast Brazil, mostly because of most of the ceramic brick industries which employs local vegetation as fuel [10]. Raw earth bricks with 
cement have the advantage of local availability; low cost; minimum generation of pollution and low power consumption in its production; humidity control in the environment, good thermal properties and ease of use in construction. Earth, when applied correctly, produces quality construction and is ideal especially for social and low cost housing (Figure 2).

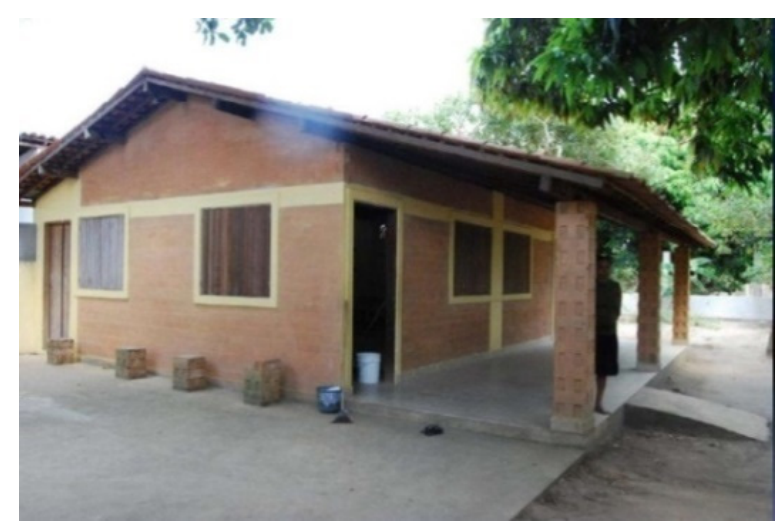

Figure 2: House in the countryside of Paraíba using raw earth blocks. (Source: http://pt.slideshare.net/CATCE/materiais-no-convencionais)

Among the main construction waste generated in João Pessoa, capital of Paraíba, is found bricks, tiles, sand, wood and concrete. Such waste can be recycled and used, for example as aggregates for concrete and mortar composition.

In the laboratories of local federal public universities, there are studies on the use of construction waste for the manufacture of mortar, such as the waste of ceramic, granite, kaolin and crushing. This practice generates many advantages, as well as using debris from construction. The product generated, which is, the mortar with recycled aggregate, can be tougher and more advantageous than conventional mortar [11]. Such recycled aggregates can also be applied to the manufacture of concrete, a material widely used in the field of construction in Brazil and the Northeastern context.

In Paraíba, another important highlighted residue is the EVA (Ethylene Vinyl Acetate), resulting of the production of local sandals factories. This waste can be employed as lightweight aggregate generating the possibility of creating sealing blocks with this material (Figure 3).

This block, called EVAi (Interlocked Block containing Ethylene Vinyl Acetate) brings improvements to the production process, for both the mechanical performance, light weight and geometry of the components of the appropriate dimensions. The thermal performance of masonry blocks with EVAi is better compared to conventional walls with ceramic brick. Besides this, the interlocking geometry has benefits for social housing project matters regarding usual adjustments of the dimensions of the components in masonry, reducing the waste [12]. 

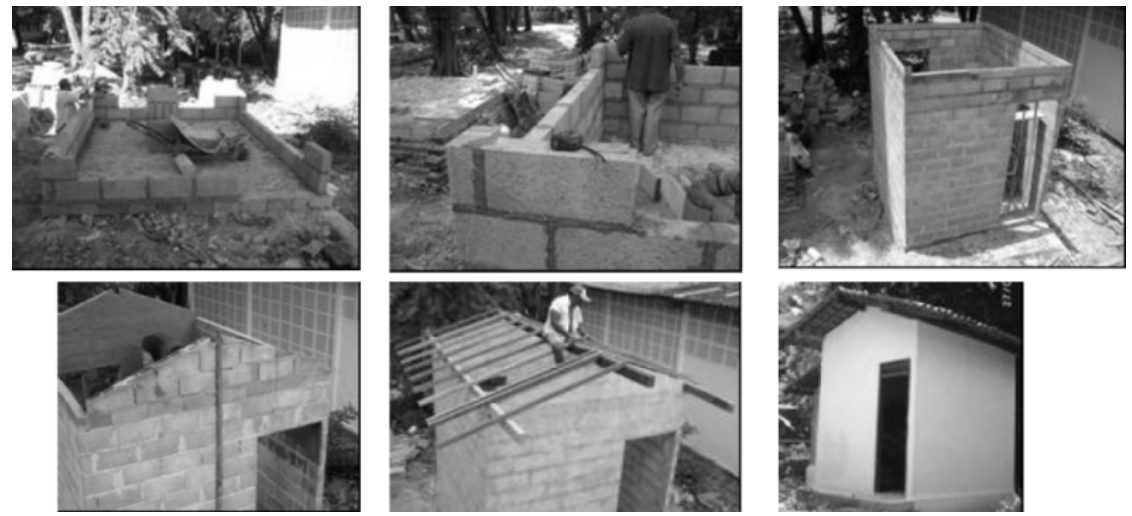

Figure 3: Execution of prototype using EVAi blocks in the Federal University of Paraíba area. (Source: www.seer.ufrgs.br/ambienteconstruido/ article/view/9471)

As for conventional waste, the adoption of solutions which help and facilitate the recycling process is very important. In this context, the technology of underground waste capture is a viable alternative for Brazilian and Northeastern cities because they do not require high technology and reduce the cost of collection. In Brazil, only a few cities have this technology focused on strategic points of the same, none of them are located in the state of Paraíba and only one in the Northeast (in Salvador, Bahia), so encouraging the implementation of this measure is of paramount importance.

Brazil has the great advantage of being able to plan its own energy matrix using large amounts of renewable primary sources. In Northeast, due to favorable climatic conditions, there is a great potential for development in the use of solar and wind energy, therefore encouraging these practices contributes to sustainable development. The Northeast region which is home for most of the wind farms, is considered the main wind power hub of the country. Solar energy through photovoltaic panels is expensive and requires a huge investment, but their use has a major benefit in the long run.

Yet in this field of study, there is a possibility of generating energy through the burning of sugar cane bagasse. This process must be considered because it reduces the environmental impact and is economically viable, as it is produced with its residue, the bagasse. An important note is that this biomass is the largest amount of the country's and region agro-industrial waste. There are also studies to use the ash generated in the combustion process as an aggregate for cement and fertilizer for future crops, which further reduces potential environmental impacts generated by this process [13].

Regarding the environmental comfort, it is undeniable the importance of design considering the solar orientation building façade and to seek for methods of ventilation and passive lighting. For the bioclimatic zoning where most of the state of Paraíba and Northeast region is inserted, the use of large and fully shaded 
openings, as well as the use of crossed ventilation throughout the year are essential and help to reach good thermal performance.

The adoption of measures such as roofs with large overhangs, brise soleil, perforated blocks, protected façades, definition of air inlets and outlets, reduced use of glass façades with higher sunlight incidence, natural lighting and ventilation are solutions which if properly applied in architectural design will represent significant reduction in energy consumption.

The region studied presents certain difficulties regarding the water supply, so solutions which encompass the capture of rainwater and internal recycling of water in buildings are significantly important. These systems can be applied to the Northeast context without many difficulties.

According to the Efficient House project developed from the partnership between and PROCEL (National Program for Energy Conservation) and Labee (Laboratory of Building Energy Efficiency) UFSC (Federal University of Santa Catarina) after disposal of unwanted solids and diversion of water from the first rains, with the presence of impurities coming from the washing of the atmosphere and catchment areas, the water collected on the roof is stored in a cistern, and later pumped to a tank top. This water is intended for supplying points aimed for nonpotable activities due to the risk of contamination of the water collected [14].

The Efficient House project also uses a gray and black water reuse system, where the house sewage facilities have been designed with the separation of effluents, a route with black water (primary sewer toilet), along with the kitchen sink of water, and another, with only the gray water from sinks, tank, washing machine and shower. Thus, these effluents are sent to different avenues of treatment, use and disposal [14].

This recycled gray and black water can be used for activities which do not involve the use of potable water, such as garden watering, washing floors etc.

The use of a green roof contributes to the collection of rainwater, and is a good option for achieving environmental comfort of the building, besides contributing to reduction of the environmental pollution and improvement of the aesthetic appearance as a whole. Another option for saving water is, as in the case studies surveyed, using devices that consume less water, such as washing machines, toilets, sinks etc. Although these devices are more expensive, they make up for the cost/benefit in the long run, decisively contributing to reducing the use of it.

\subsection{Case study of a sustainable building in Paraíba}

The new headquarter of Energisa company, located in the countryside of Paraíba in Patos, designed by the architect Arthur Brazilian, managed to obtain the LEED (Leadership in Energy and Environmental Design) Silver certification in all categories. The building was designed to follow international standards in sustainability. It based the project on the air conditioning of space and use of reuse of rainwater systems, which is a scarce element in the region (Figure 4).

The building uses white thermo-acoustic tiles which largely reflects the sunlight and decreases the internal temperature. Metal louvers are used to reduce the sunlight on the façades and the windows are made of laminated glass with low solar factor which lets the natural light in and prevents heat transfers to the inside. 
In the paving, flooring grass and interlocked floor is used allowing water to pass through and reach the ground floor [15].

The building also uses taps with automatic closing and exhausting valves with double drive for water economy; water-based paints, varnishes and plant resins with low VOC content (volatile organic compound); recycled metal in the fences demarcating the land and infrared sensors presence and PL lamps which saves up to $22 \%$ energy compared to standard lamps [15].

This architectural design summarizes in parts as how it is possible to design a sustainable and environmentally certified building following Life Cycle Analysis precepts in the interior of Paraíba despite the climatic and economic conditions.

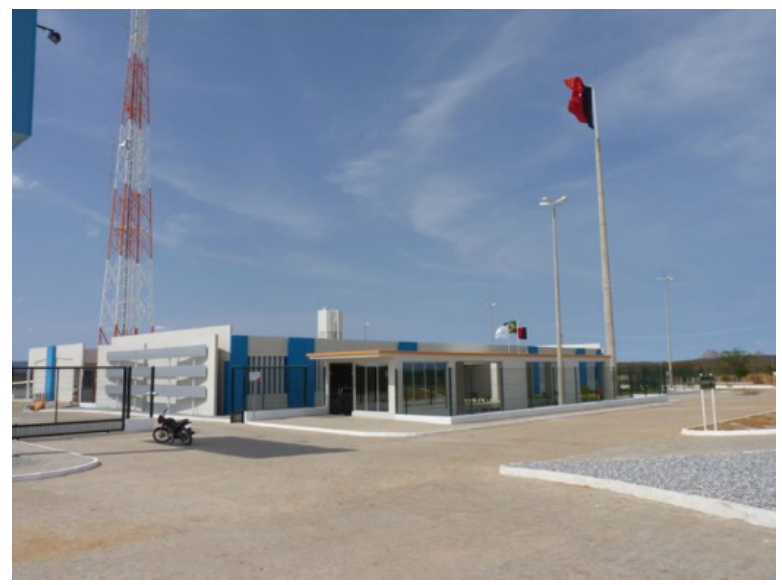

Figure 4: New headquarters of Energisa Paraíba. (Source: http://www.otec. com.br/103-56/)

\section{Final considerations}

The life cycle assessment proves to be a very efficient method for reaching sustainability. Its adoption brings numerous benefits not only for the architectural design, but especially for the environment.

The four architectural housing projects have shown that it is possible to design and build aiming sustainable architecture, and that this can perfectly function if there is planning and organization previously outlined. Several technologies are available nowadays, and we can use them in our advantage in to achieve our goals.

This study proved to be of great importance, not only for the understanding of what is a sustainable construction through LCA, but also to prove that it is possible to apply the concept of sustainability and efficiency in architecture in our region without great technologies, construction techniques and elevated costs. It is possible to build with low costs. Besides local material and local techniques construction can and must be used in this context to our advantage. Unfortunately, there are still a few numbers of architectural buildings considered to be sustainable or certified in Paraíba. Therefore, the incentives to these construction practices 
covering sustainability are increasingly important to ensure sustainable and promising development.

\section{References}

[1] Campos, F.H.A. Análise do Ciclo de Vida na Construção Civil: Um estudo comparativo entre vedações estruturais em painéis pré-moldados e alvenarias em bloco de concreto. Dissertação de Mestrado, Programa de Pós Graduação em Construção Civil da Escola de Engenharia da Universidade Federal de Minas Gerais, Belo Horizonte, 2012.

[2] Edwards, B. O guia básico para a sustentabilidade. Editora GG, Barcelona, pp. 114-155, 2008.

[3] Francisco, W. C. E. "Aspectos naturais da Paraíba"; Brasil Escola. URL: $<$ http://brasilescola.uol.com.br/brasil/aspectos-naturais-paraiba.htm>.

[4] Murdoch, C; Figuereido, A. BedZed, Caderno de Boas Práticas em Arquitetura - Eficiência Energética, pp. 12-15, 2008

[5] Barbosa, E. Estocolmo 2030 e a sustentabilidade urbana aplicada. Cidades Verdes, v. 1, n. 1, pp. 117-139, abr. 2013.

[6] Ferreira, M. T. Construir no Construído: Nó de Alcântara, Novos Pólos de Urbanidade Multifuncionais e Sustentáveis. Dissertação de Mestrado em Arquitetura, Universidade Técnica de Lisboa, Lisboa, 2012.

[7] Goresko, J. Darmstadt Kranichstein Passive House Study, 2012. URL: $<$ http://www.greendesignetc.com/Building_12/GreenBuildiing_Goresko_J ulian_Paper.pdf>

[8] Sobrinho J. A. Comportamento estrutural de painéis contendo bambu e resíduos industriais para habitações de interesse social. Dissertação de Mestrado, Programa de Pós Graduação em Engenharia Urbana da Universidade Federal da Paraíba, João Pessoa, 2006.

[9] Silva, C. Inovações tecnológicas para melhor aproveitamento do gesso nas construções. Dissertação de Mestrado, Programa de Pós Graduação em Engenharia Urbana e Ambiental da Universidade Federal da Paraíba, 2010

[10] Barbosa, N; Mattone, R; Mesbah, A. Blocos de Concreto de Terra: Uma Opção Interessante Para a Sustentabilidade da Construção. Minas Gerais, $44^{\circ}$ Congresso Brasileiro de Concreto. Belo-Horizonte, 2002.

[11] Lima, F. Aproveitamento de resíduos da construção na fabricação de argamassas. Dissertação de Mestrado, Programa de Pós Graduação em Engenharia Urbana da Universidade Federal da Paraíba, João Pessoa, 2005.

[12] Rocha, F; Melo, A; Torres, S; Silva, E. Pré-moldado (bloco EVAi) para alvenaria intertravada: projeto, produção, desempenho e simulação de uso em habitação social. Ambiente Construído, Porto Alegre, v. 13, n. 2, pp. 4760, abr./jun. 2013.

[13] Filho, P. L. Análise de custos na geração de energia com o bagaço da cana de açucar. Dissertação de Mestrado, Programa de Pós Graduação em Energia da Universidade de Sâo Paulo, São Paulo, 2009. 
[14] Lamberts, R. et al. Casa eficiente: consumo e geração de energia. Florianópolis: UFSC/LabEEE; $2010 . \quad$ v. 2 (76 p.) URL: http://www.eletrosul.gov.br/casaeficiente/br/home/index.php

[15] Lima, M. Conjunto de edifícios no sertão nordestino recebe certificação de sustentabilidade, 2002. URL: <http://piniweb.pini.com.br/construcao/ sustentabilidade/conjunto-de-edificios-no-sertao-nordestino-recebecertificacao-de-sustentabilidade-251143-1.aspx> 